\title{
P 315
}

京都府下中小企業における安全衛生委員会の活性化に関する調査研究

\author{
○江峷 高史 1）2）、池田正之1）、乾 修然11 \\ (財京都工場保健会 1) 京都産業保健推進センター2)
}

【はじめに】京都では平成 7 年に産業保健推進センターが開所し、同年京都府下の中小企業 3818 事業場に対し産業保健活 動の实態を調查するためアンケートを行った結果、635社より回答を頂いた。その中で、企業の安全衛生活動の基盤となる ベき安全衛生委会会の活動状況は、毎月開催している事業場が $51 \%$ にすぎず、1年間開催していない事業場も $23 \%$ あつ た。そこで今回我々は、この拥查で「安全衛生委貝会を毎月実施している」との回答を得た事業場を対象に、その連営や活動 内容等を調查したので報告する。

【対象および方法】学儌者 50 人以上で安全衛生委置会を毎月実施しているとの回答を得た事業場のうち 130 事業場を対象 とした。平成 8 年に「中小企業の衛生（安全衙生）委貴会の活性化に関するアンケート」を郵送にて配布、回収を行い70事 業場から回答を得た。

【結果および考察】回答害業場は産業別では製造業68\%、規模別では50〜99人が40\%であった（図 1、2）。

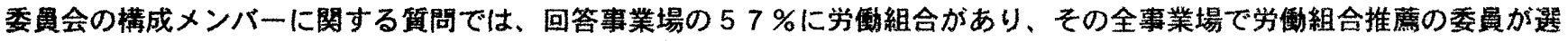

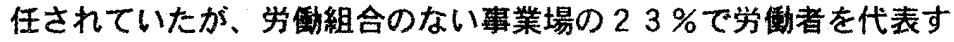
る委買が選任されておらず、委買会活動に労働者の意見が反映され にくい構成であった。産業医の委買としての選任状況も $71 \%$ ， 作業環境測定士や産業看護職は9\%によどまった。

委賀会の開催に関する質問では、開催時間が就業時間内であった 事業場は $90 \%$ 、就業時間外であると回答した 5 事業場 $7 \%$ の理 由としては、货物運送業とビルメンテナンス業の 2 事業場は事業の 性質上委賁が揃いやすいという理由、他の3事業場は安全衛生委员 会を生産会境の後に行うためとのことで委員は㦹制が兼ねていると の回答であり、委員会出席時の軼金保障も上記の 5 社中 4 社は保障 されていなかった。

開催回数は毎月 1 回開催している事業場が $34 \% 、 1$ 年間 13 回 以上開催している事業場も $45 \%$ あった。年回 14 回開催した所が 22 事業場と多く毎月 1 回の定例委賁会と安全週間と徫生週間の前 に週間準潇、安全衛生㯲語の選考委買会などを開催しているとの回 答が多かった。

委貫会の番議・付議事項についての設問では労働災害の原因再発 防止対策、安全衛生管理の年間計画の審議、安全衛生教育に関する こと、健康診断の実施に関することが $80 \%$ よの事業場で賽議さ れている一方、THP（健康づくり）対策 $50 \%$ 、疾病予防対策 5 $4 \%$ 、機械設備等の労街衛生面の審議 $56 \%$ と少ない。健康診断の 事後措㩖に関しては規模別で大きな差を憶めた（図3）。

安全衛生委買会での安全に関する事項亡衛生に関する事項の審議 割合についての設問では衛生に関する審議割合が $51 \%$ $1 \%$ 上あの は4 事業場 $6 \%$ とまだまだ委買会は安全事案が優位である現状であ り、眭代の変化で衛生問題が重要性を增している現在娄買会での問 題提起、活動内容の改萻が必要である。

産業医の活動亡委費会との関係に関しての設問では、衛生事案に 䙳門的意見が出されるとの回答は35\%であるが、産業医の意見は 少ない3 $5 \%$ 、意見がない1 $6 \%$ であり企業における産業保健向上 の基盤を築く安全衛生委量会での産業医の專門的活動はまだ一部の 電業場でしか行われていない状況を示していた（図4）。

【まとめ】産業医の専門性の確保や健康彭断の事後措置の徹底を図 る規定が強化され事業場における㕍業保健活動の充実が求められて いる現在、中小企業において産業医が安全衛生委員会の活性化に重 要な役割を果たすことが必要である。

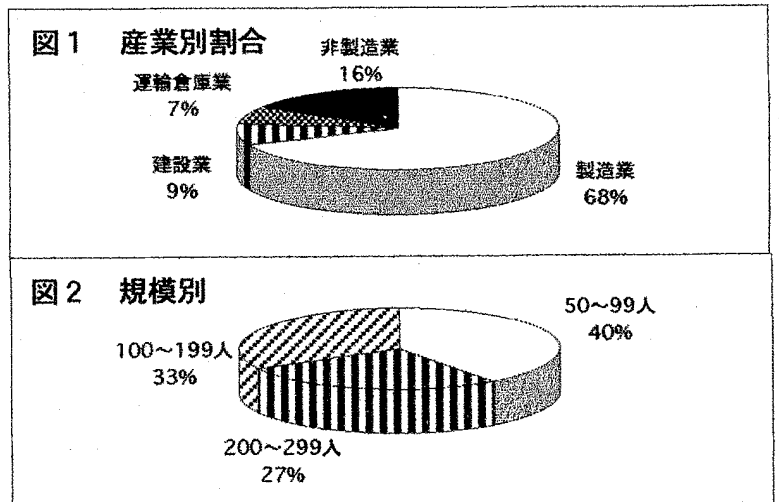

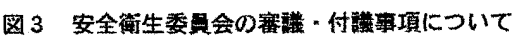

安全衛生管理の

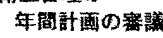
安全衛生管理社内規定 の寒 网すること

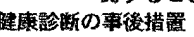

作業珝境测定の㖀価

疾病予防対策

設嚾棬棫、新業務、

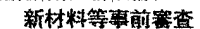
THP

(健康つくく) 対策 学儌淛害の原因 再発防上対策 設满機械の安全化 安全衙生教裔に 関すること

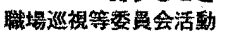
回答なし

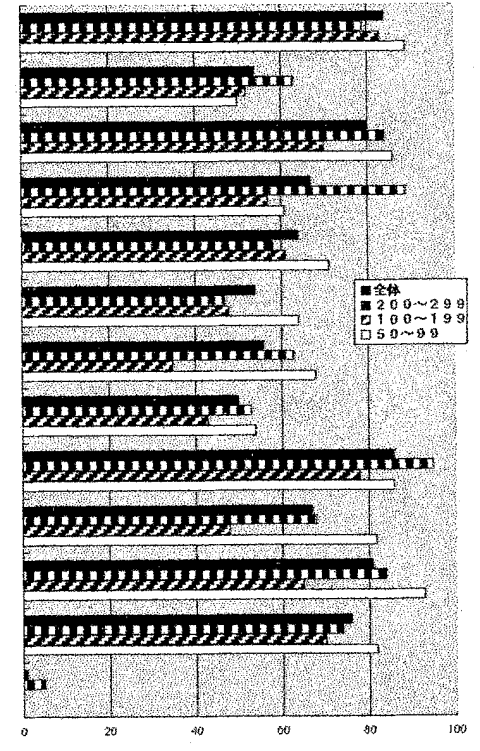

图 4 業医の活動と委員会との関係について

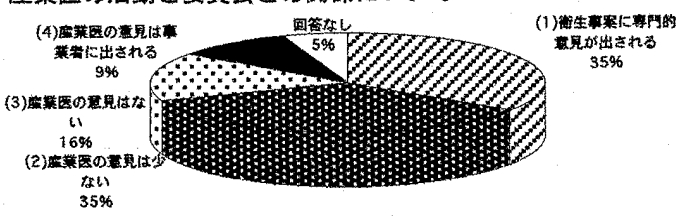

